\title{
Handmade paper from waste banana fibre
}

\author{
K. M. Y. Arafat ${ }^{1}$, J. Nayeem ${ }^{1}$, A. H. Quadery ${ }^{1}$, M. A. Quaiyyum ${ }^{2}$ and M. Sarwar Jahan ${ }^{1 *}$ \\ ${ }^{I}$ Pulp and Paper Research Division, BCSIR Laboratories, Dhaka, Dr. Qudrat-i-Khuda Road, Dhaka-1205, Bangladesh \\ ${ }^{2}$ Department of Applied Chemistry and Chemical Engineering, Dhaka University, Dhaka, Bangladesh
}

Received: 14 December 2017

Revised: 31 December 2017

Accepted: 31 Janurary 2018

DOI: http://dx.doi.org/10.3329/bjsir.v53i2.36668

\begin{abstract}
Banana fibre is a natural fibre with high strength, which can be blended easily with cotton fibre or synthetic fibre to produce composite material. In the fiber extraction process, a substantial amount of lignocellulosic wastes are generated, disposal of which creates problem in the adjacent area. In this paper, extracted banana fiber (EBF) and waste banana fiber (WBF) were characterized in terms of chemical and morphological properties to produce handmade paper. WBF was characterized with lower $\alpha$-cellulose, lignin content and longer fiber length. Pulping of EBF and WBF was carried out with varying active alkali and cooking time at boiling temperature. Pulp yield of WBF was $35.9 \%$ after 120 min of cooking with $8 \%$ alkali charge. In the unbeaten state the degrees of drainage resistance i.e. SR values were 65 and 71 for $\mathrm{EBF}$ and $\mathrm{WBF}$, respectively. The tensile, burst and tear indices of $\mathrm{WBF}$ were $23.7 \mathrm{~N} . \mathrm{m} / \mathrm{g}, 2.2 \mathrm{kPa} . \mathrm{m}^{2} / \mathrm{g}$ and $5.0 \mathrm{mN} . \mathrm{m}^{2} / \mathrm{g}$, respectively; these were much lower as compared to EBF. These values however, meet the requirement for handmade paper.
\end{abstract}

Keywords: Banana wastes; Waste banana fiber; Extracted banana fiber pulping; Handmade paper

\section{Introduction}

Banana (Musa paradisiaca, family Musaceae) is a major fruit crop of the tropical and subtropical regions of the world grown on about 8.8 million hectares (Mohapatra et al., 2010). Bangladesh produced 770203 tonnes of bananas in 2014 (FAOSTAT 2017).

Banana (Musa paradisiaca) grows almost everywhere in Bangladesh round the year. Banana crop produces large quantities of post-harvest biomass wastes. Currently $37,40,096$ tons of waste are dumped annually as waste from which banana fibre can be extracted. Some of them are a potential resource of raw materials such as natural fibers, which can be used as reinforcement for composite materials. A good number of methods have so far been studied for the extraction of banana fiber. Anaerobic digestion of soft tissues of banana wastes separated fibers (Wobiwo et al., 2017). Yilmaz et al., (2017) extracted fibres from fruit and bunch stems of banana plant by water retting and showed that bunch stem fibres were superior in terms of fineness, initial modulus and breaking strength. Ganan et al. (2004) extracted banana fibre from stem and bunch of banana waste by alkalization and silanization followed by mechanical treatment. The extracted banana fibre has been studied for reinforcing material for lignocellulosic composite materials (Alavudeen et al., 2015; Joseph et al., 2006; Srinivasababu et al., 2009), pulp (Rahman et al., 2014), cellulose microfibrils (Cherian et al., 2008; Elanthikkal et al., 2010). Spin ability of banana fibre, fineness and tensile strength make it usable in a number of different textiles with different weights and thicknesses, based on what part of the banana stem the fibre was extracted from. Enzymatic treatment of extracted banana fibers spinning showed suitability of yarns production (Ortega et al., 2016).

The Banana fiber extraction machine has been developed by local innovator as shown in Fig. 1. The extraction can be done mainly in three ways: manual, chemical and mechanical. In this machine, fibre extraction is done by mechanical extraction process, which is eco-friendly way to get fiber of both good quality and quantity. In this process the fiber is extracted by inserting the pseudo stem sheaths one by one into a machine. Water and non-fibrous elements are removed from the bottom of the machine. Extracted banana fibers are being exported to overseas market. During the extraction process, substantial amount of wastes are generated, which are mainly non-fibrous element.

\footnotetext{
*Corresponding author e-mail: sarwar2065@hotmail.com
} 
Local entrepreneur are facing problems in disposing the accumulated waste. There is an urgent need to handle this waste by appropriate processing method considering environmental problem. In this regard, it may be worth noting that Bangladesh government has banned polyethylene bag to protect the environment. Therefore, 40,000 workers in about 400 polyethylene bag factories have lost their jobs. Therefore, interest is growing up to build biodegradable bag industry. Many cottage industries are growing for manufacturing paper bag based on recycling paper. These bags could not meet the demand of user because of lower strength.

The physical, morphological and chemicals characteristics of different Musa species were studied by Omotoso and Ogunsile (2010) and found that Musa species were rich in cellulose and low in lignin content compared to hardwood. The fibre lengths were varied from medium to longer range from species to species. Many studies have been reported on the pulping of banana fibre (Heikal, 1976; Heikal and Fadl, 1977; Rahman et al., 2014). Pulping of retted and unretted banana plant fibre were carried out by (Heikal, 1976; Heikal and Fadl, 1977) and it was observed that pulping of retted samples produced pulps with improved chemical and physical properties than that from of unretted samples. In this work, wastes from banana fibre extraction plant were characterized in terms of chemical and morphological properties and compared with extracted banana fiber (EBF) from the same banana fibre extraction plant. Pulping of waste banana fibre (WBF) and EBF was also carried out by varying alkali charge, and cooking time at the boiling temperature. Finally, we aimed at producing handmade paper from WBF.

\section{Materials and methods}

\section{Materials}

$\mathrm{EBF}$ and WBF were collected from the local banana fibre extraction unit in the district of Dinajpur, Bangladesh and sun dried. The EBF was cut to $2-3 \mathrm{~cm}$ in length. The moisture content of EBF and WBF was determined for the subsequent experiments.

\section{Morphological properties}

For the measurement of fibre length, EBF and WBF was macerated in a solution containing $1: 1 \mathrm{HNO}_{3}$ and $\mathrm{KClO}_{3}$. Six gram $\mathrm{KClO}_{3}$ was dissolved in $50 \mathrm{ml} 70 \% \mathrm{HNO}_{3}$ and $50 \mathrm{ml}$ distilled water. A drop of macerated sample was taken on a slide and fiber length was measured under a digital microscope (Labomed, USA). Fibre width was determined from the cross-section of the photograph taken in an image analyzer using appropriate software.

\section{Chemical analysis}

The cold and hot water solubility (T207 cm99), 1\% alkali solubility, extractives (T204 om88), Klason lignin (T222 om98), pentosan (T223 cm01) and ash content (T211 om93) were determined in accordance with Tappi Test Methods. For the determination of cold water solubility, ground raw material was extracted with reagent grade water at $25^{\circ} \mathrm{C}$ with stirring for $48 \mathrm{~h}$. For the determination of hot water solubility, ground raw material was extracted with reagent grade water under reflux in a boiling water bath for $3 \mathrm{~h}$. For lignin determination, the carbohydrates in raw material were hydrolyzed and solubilized by $72 \%$ sulfuric acid; the acid-insoluble lignin is filtered off, dried, and weighed. For pentosnan determination, pentosan are transformed in boiling $3.85 \mathrm{~N}$ hydrochloric acid to furfural, which was collected in the distillate and determined colorimetrically with orcinol-ferric chloride reagent. For ash determination, a test specimen is ignited in a muffle furnace at $525^{\circ} \mathrm{C}$. The resulting weight of ash was calculated the percentage ash present at $525^{\circ} \mathrm{C}$.

Holocellulose was determined by treating extractive-free wood meal with $\mathrm{NaClO}_{2}$ solution (Browining, 1967). The $\mathrm{pH}$ of the solution was maintained at 4.0 by adding acetate buffer.

\section{Pulping}

Pulping of EBF and WBF was carried out in an electrically heated open digester with constant stirring device. The pulping was carried out under the following conditions:

- $\quad$ Active alkali: 8, 10 and $12 \%$ as $\mathrm{NaOH}$.

- $\quad$ Time: 90, 120, $150 \mathrm{~min}$ at the boiling temperature.

- $\quad$ Liquor to feedstock ratio: 8:1

- $\quad$ Temperature: boiling

During cooking, the constant volume of the liquor inside the digester was maintained by adding hot water. After completing digestion time, pulp was washed with tap water till the removal of all chemicals. The pulp yield was determined gravimetrically from the oven-dried weight of EBF and WBF. The kappa number, an indication of the residual lignin content or bleachability of the resulting pulp, was determined in accordance to Tappi Test Methods (T 236 om-99).

\section{Evaluation of pulp}

EBF and WBF pulps were disintegrated in a standard disintegrator. The handsheets of about $60 \mathrm{~g} / \mathrm{m}^{2}$ were made in 
a Rapid Köthen Sheet Making Machine according to German Standard Methods. The sheets were tested for tensile, (T 494 om-96), burst (T 403 om-97), and tear strength (T 414 om-98) according to TAPPI Standard Test Methods.

\section{Results and discussion}

\section{Chemical and morphological characteristics}

Table I shows chemical and morphological properties of EBF and wastes from banana fiber extraction process i.e. WBF. There was a significant difference of chemical properties of the two lignocellulosic sources except hot and cold water solubilities. One percent alkali extracts of EBF was $29.26 \%$, while the same for WBF was $41.2 \%$. This large difference parenchyma and porosity of the tissue. The Klason lignin content in EBF was only $13.2 \%$, which was close to jute fiber (Jahan et al., 2007). On the other hand, Klason lignin content in WBF was slightly higher than that of EBF (16.4\%), but still lower than wood (Goyal et al., 1999). The lignin content in this study is very close to the result obtained by Rahman et al. (2014). Lower lignin content indicated as an easier pulping in alkaline medium. A large difference was observed between EBF and WBF in holocellulose and $\alpha$-cellulose content. The holocellulose and $\alpha$-cellulose content were $67.2 \%$ and $44.5 \%$ for EBF and $33.7 \%$ and $22.4 \%$ for $\mathrm{WBF}$, respectively. A very low $\alpha$-cellulose content suggested the use for handmade paper, not for machine made paper. The pentosan content was also found very low, $12.9 \%$ for $\mathrm{EBF}$ and $10.4 \%$ for WBF. The mineral components of

Table I. Chemical and morphological properties of EBF and WBF

\begin{tabular}{lcc}
\hline & EBF & WBF \\
\hline Extractive, acetone (\%) & 3.0 & 4.2 \\
One percent alkali solubility (\%) & 41.2 & 29.3 \\
Hot -water solubility (\%) & 22.2 & 21.1 \\
Cold water solubility (\%) & 12.4 & 11.7 \\
Klason lignin (\%) & 13.2 & 16.4 \\
Pentosan (\%) & 12.9 & 10.4 \\
Holocellulose (\%) & 67.2 & 33.7 \\
$\alpha$-cellulose (\%) & 44.5 & 22.4 \\
Ash (\%) & 10.4 & 13.8 \\
\hline Fiber length, L (mm) & 3.1 & 2.0 \\
Fiber width, D ( $\mu \mathrm{m})$ & 20 & 20 \\
Slender ratio (L/D) & 155 & 100 \\
\hline
\end{tabular}

can be explained by the presence of non-fibrous cell in WBF, which is dissolved in $1 \%$ alkali. In our previous study it was reported that one percent alkali solubility of banana stem, leaf and kadhi was 51.4, 32.4 and 49.4\%, respectively (Rahman et al., 2014). Typical high solubility in $1 \% \mathrm{NaOH}$ indicated that easy access and degradation of the cell wall material occurred by weak alkali. These extractives were higher as compared to other grasses (Radiotis et al., 1999). The high hot water solubility revealed the presence of many soluble carbohydrates and phenolics as well as the effect of lignocellulosic biomass are represented as ash content. The ash content in WBF was higher than in EBF (13.8 vs 10.4). Higher ash content is undesirable during chemical recovery in the process. It is well established that transition metals such as $\mathrm{Mn}, \mathrm{Fe}$ and $\mathrm{Cu}$ negatively affect pulp bleachability (hydrogen peroxide and oxygen) and bleaching selectivity (Cao et al., 2014).

Papermaking properties of a raw material is dependent on fibre morphology, which are also shown in Table I. The 
Table II. Cooking of EBF and WBF

\begin{tabular}{cccccc}
\hline NaOH charge & Cooking time & \multicolumn{2}{c}{ EBF } & \multicolumn{2}{c}{ WBF } \\
\cline { 3 - 6 }$(\%)$ & $(\mathrm{min})$ & Pulp yield & Kappa & Pulp yield & Kappa \\
& & $(\%)$ & number & $(\%)$ & number \\
\hline 8 & 90 & 66.8 & $*$ & 38.8 & $*$ \\
10 & 90 & 62.5 & $*$ & 36.4 & $*$ \\
12 & 90 & 59.6 & 37.0 & 35.0 & 37.6 \\
\hline 8 & 120 & 63.4 & 37.4 & 35.9 & 37.6 \\
10 & 120 & 56.5 & 32.6 & 34.0 & 33.9 \\
12 & 120 & 48.9 & 31.7 & 32.9 & 32.1 \\
\hline 8 & 150 & 60.3 & 33.7 & 33.0 & 34.9 \\
10 & 150 & 55.2 & 30.1 & 31.8 & 31.2 \\
12 & 150 & 46.7 & 29.4 & 29.3 & 29.9 \\
\hline
\end{tabular}

* Were not defibrated in disintegrat ion

Table III. Papermaking properties of EBF and WBF

\begin{tabular}{lcc}
\hline & EBF & WBF \\
\hline Drainage resistance $\left({ }^{\circ} \mathrm{SR}\right)$ & 65 & 71 \\
Tensile index $(\mathrm{N} . \mathrm{m} / \mathrm{g})$ & 83.8 & 23.7 \\
Burst index $\left(\mathrm{kPa} . \mathrm{m}^{2} / \mathrm{g}\right)$ & 8.2 & 2.2 \\
Tear index $\left(\mathrm{mN} . \mathrm{m}^{2} / \mathrm{g}\right)$ & 18.1 & 5.0 \\
\hline
\end{tabular}

average fibre length of EBF and WBF was 3.1 and $2.0 \mathrm{~mm}$, respectively. Lower fibre length in WBF can be explained by the presence of broken fibre. Rahman et al. (2014) obtained fibre length of banana pseudo stem was $2.21 \mathrm{~mm}$, which was lower than the EBF in present study. A higher fibre length showed higher tearing strength of paper. Higher fibre length in EBF can be explained by the separation of all nonfibrous cell, short fibre were removed in the extraction process. Fibre lengths were comparable to those of jute bast fibre (Jahan et al., 2007), kenaf bast fibre (Ververis et al., 2004) and softwood fibre. Omotoso and Ogunsile (2010) showed that the fibre length of Musa paradisica stem was $2.83 \mathrm{~mm}$. Paper formed by thin-walled fibre would be dense and well formed
(Ververis et al., 2004). Slenderness ratio (fibre length/fibre diameter) affects the paper properties positively. As shown in Table I, EBF showed higher slenderness ratio (155) compared to Cyperus flabettiformic grass (111.7) (Jahan et al., 2016). Generally, it is considered that if the slenderness ratio for the fiber is less than 70 than pulp would have poor strength (Ververis et al., 2004).

Light microscopic results showed that the WBF was constituted by homogeneous parenchyma cells and the fiber, while EBF was constituted mainly by fibre (Fig. 2). The fibres are the important cells for pulping and papermaking properties. 


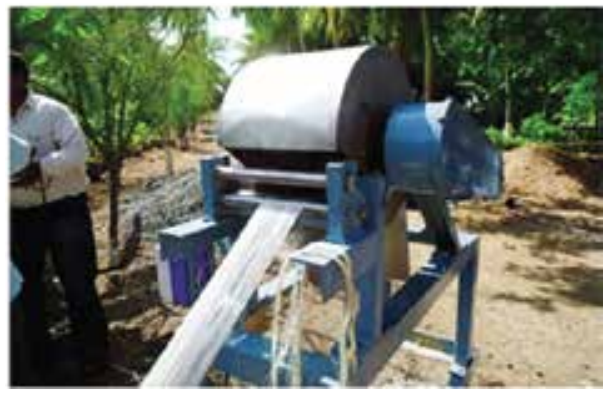

Fig. 1. Photograph of locally fabricated banana fiber extraction machine

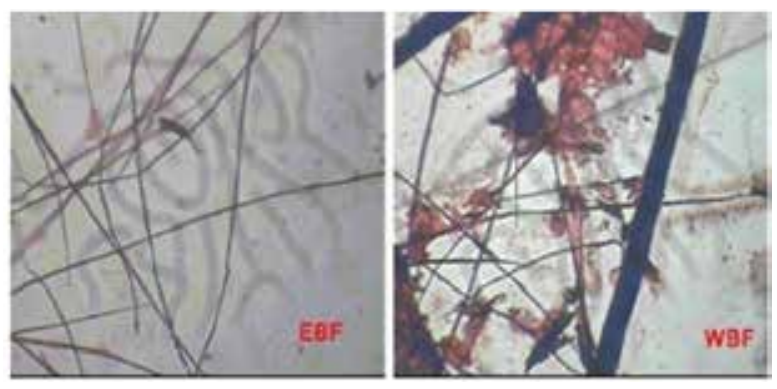

Fig. 2. Microphotograph of EBF and WBF

\section{Pulping}

Soda pulping of EBF and WBF was carried out with varying cooking time and alkali charge at boiling temperature and results are shown in Table II. As expected decrease in pulp yield and kappa number was marked with increasing cooking time or active alkali content. EBF showed higher pulp yield than WBF. Pulp yields were $46.7-66.8 \%$ for EBF and $29.3-38.8 \%$ for WBF. The higher pulp yield can be explained by higher $\alpha$-cellulose content in EBF (Table I). In 90 min of cooking with 8 and $10 \%$ alkali charge, fibres were not defibrated after disintegration; therefore, kappa number was not determined. Although in the present case kappa number is not important as it was targeted to supply raw material for handmade paper. Kappa number of these two raw materials did not reach below 29 in our applied conditions. In our previous study, banana peduncle portion produced pulp with kappa number 16 at $22 \%$ active alkali charge, while leaf stalk and pseudo stem reached to kappa number 24 and 25 at the alkali charge of $16 \%$, respectively. Peduncle needed high alkali charge than other two parts, which was due to the fact that high amount of mineral restrains in this portion to consume alkali during pulping (Rahman et al., 2014). Pulp yield of WBF was $35.9 \%$ after 120 min of cooking with $8 \%$ alkali charge, which was decreased to $33.0 \%$ with increasing cooking time to $150 \mathrm{~min}$. Our target was to get defibrated fibre with maximum pulp yield by minimum alkali charge. So WBF can be used in rural area for handmade paper with minimum capital investment. In this consideration, cooking with $8 \%$ alkali charge for 120 min was optimum condition for production of handmade paper from WBF.

\section{Papermaking properties}

The strength properties of EBF and WBF pulps obtained under optimum conditions were determined in the unbeaten state. Pulp beating was avoided as our main target of this study was to utilize WBF as a source of raw materials for handmade paper. In the unbeaten state the degrees of drainage resistance i.e SR values were 65 and 71 for EBF and WBF, respectively. A high SR value can be explained by presence nonfibrous cells and fines, which are evident in Fig. 2. Goswami and Roy (2008) showed that banana pulp is easily beatable and reaches high degree of SR at short beating time. The tensile index of EBF was 83.8, which is higher than other grass type pulp (Jahan et al., 2006; 2007a). A high tear index $\left(18.1 \mathrm{mN} . \mathrm{m}^{2} / \mathrm{g}\right)$ was obtained for EBF pulp. This is due to higher fibre length as shown in Table I. The tensile, burst and tear indices of WBF were 23.7 N.m/g, 2.2 $\mathrm{kPa} . \mathrm{m}^{2} / \mathrm{g}$ and $5.0 \mathrm{mN} . \mathrm{m}^{2} / \mathrm{g}$, respectively, those were much lower for EBF. But these values are quite acceptable for handmade paper.

\section{Conclusions}

WBF contains very low amount of $\alpha$-cellulose and high amount of ash. WBF is constituted by fibers, broken fibers and nonfibrous cells. At 120 min of cooking with $8 \%$ alkali charge, WBF is defibrated with pulp yield of $35.9 \%$. Initial SR value of EBF pulp is very high (65) and consequently increases to a very high tensile strength. Tear index of EBF is also very high due to the longer fiber length. The papermaking properties of WBF are quite acceptable for handmade paper. But these properties are much lower as compared to EBF pulp. The waste generated in banana fibre extraction plant can be used in handmade paper which will mitigate the pollution problem along with creating employment opportunity in rural area.

\section{References}

Alavudeen A, Rajini N, Karthikeyan S, Thiruchitrambalam $\mathrm{M}$ and Venkateshwaren N (2015), Mechanical properties of banana/kenaf fiber-reinforced hybrid polyester composites: Effect of woven fabric and random orientation, Materials \& Design 66: 246-257. DOI: $10.1016 /$ j.matdes.2014.10.067

Browning BL (1967), Methods of wood chemistry, Volumes I \& II.

Cao S, Ma X, Lin L, Huang F, Huang L and Chen L (2014) Morphological and chemical characterization of green 
bamboo (Dendrocalamopsis oldhami (Munro) Keng f.) for dissolving pulp production, BioResources 9(3): 4528-4539.

Cherian BM, Pothan LA, Nguyen-Chung T, Mennig G, Kottaisamy M and Thomas S (2008), A novel method for the synthesis of cellulose nanofibril whiskers from banana fibers and characterization, Journal of Agricultural and Food Chemistry 56(14): 5617-5627.

Elanthikkal S, Gopalakrishnapanicker U, Varghese S and Guthrie JT (2010), Cellulose microfibres produced from banana plant wastes: Isolation and characterization, Carbohydrate Polymers 80(3): 852-859. DOI: 10.1016/j.carbpol.2009.12.043

FAOSTAT (2017) http://www.fao.org/faostat/en

Ganan P, Cruz J, Garbizu S, Arbelaiz A and Mondragon I (2004), Stem and bunch banana fibers from cultivation wastes: Effect of treatments on physico-chemical behavior, Journal of Applied Polymer Science 94(4): 1489-1495. DOI: 10.1002/app.21061

Goswami T, Kalita D and Rao PG (2008), Greaseproof paper from banana (Musa paradisica L.) pulp fiber, Indian Journal of Chemical Technology 15: 457-461.

Goyal GC, Fisher JJ, Krohn MJ, Packwood RE and Olson JR (1999), Variability in pulping and fiber characteristics of hybrid poplar tree due to their genetic makeup, environmental factors and tree age, Tappi Journal $\mathbf{5 3}$ (5): 141-147.

Heikal SO (1976), Nitric acid paper pulps from banana stems, Indian Pulp and Paper 31(3): 5. DOI:10.1016/j.indcrop.2003.09.001

Heikal SO, Fadl MH (1977), Mild pulping of banana stem, Research and Industry 22(4): 222.

Jahan MS, Chowdhury DN and Islam MK (2006), Characterization and evaluation of golpata fronds as pulping raw materials, Bioresource Technology 97(3): 401-406. DOI: 10.1016/j.biortech.2005.04.003

Jahan MS, Maruf AA and Quaiyyum MA (2007) Comparative studies of pulping of jute fiber, jute cutting and jute caddis, Bangladesh Journal of Scientific and Industrial Research 42(4): 425-434. DOI: 10.3329/bjsir.v42i4.750

Jahan MS, Islam MK, Chowdhury DN, Moeiz SI and Arman U (2007a), Pulping and papermaking properties of pati (Typha), Industrial Crops and Products 26(3): 259-264. DOI: 10.1016/j.indcrop.2007.03.014

Jahan MS, Uddin MN, Rahman A, Rahman MM and Amin MN (2016), Soda pulping of umbrella palm grass
(Cyperus flabettiformic), Journal of Bioresources and Bioproducts 1(2): 85-91.

Joseph S, Oommen Z and Thomas S (2006), Environmental durability of banana-fiber-reinforced phenol formaldehyde composites, Journal of Applied Polymer Science 100(3): 2521-2531. DOI: 10.1002/app.23680

Mohapatra D, Mishra S and Sutar N (2010), Banana and its by-product utilization: An overview, Journal of Scientific and Industrial Research 69: 323-329.

Omotoso MA and Ogunsile BO (2010), Fibre and chemical properties of some Nigerian grown Musa species for pulp production, Asian Journal of Materials Science 2(3): 160-67. DOI: 10.3923/ajmskr.2009.14.21

Ortega Z, Morón M, Monzón MD, Badalló P and Paz R (2016), Production of banana fiber yarns for technical textile reinforced composites, Materials 9(5): 370 . DOI: $10.3390 / \mathrm{ma} 9050370$

Radiotis T, Li J, Goel K, Eisner R (1999), Fiber characteristics, pulpability and bleachability of switchgrass, Tappi Journal 82(7): 100-105.

Rahman MM, Islam T, Nayeem J and Jahan M (2014), Variation of chemical and morphological properties of different parts of banana plant (Musa paradisica) and their effects on pulping, International Journal of Lignocellulosic Products 1(2): 93-103.

Srinivasababu N, Rao KMM and Kumar JS (2009), Experimental determination of tensile properties of okra, sisal and banana fiber reinforced polyester composites, Indian Journal of Science and Technology 2(7): 35-38.

Ververis C, Georghiou K, Christodoulakis N, Santas P and Santas R (2004), Fiber dimensions, lignin and cellulose content of various plant materials and their suitability for paper production, Industrial Crops and Products 19: 245-254. DOI: 10.1016/j.indcrop.2003.10.006

Wobiwo FA, Alleluya VK, Emaga TH, Boda M, Fokou E, Gillet S, Deleu M and Gerin PA (2017), Recovery of fibers and biomethane from banana peduncles biomass through anaerobic digestion, Energy for Sustainable Development 37: 60-65. DOI: 10.1016/j.esd.2017.01.005

Yilmaz ND, Sulak M, Yilmaz K and Khan GM (2017), Effect of chemical treatments on physico-chemical properties of fibres from banana fruit and bunch stems, Indian Journal of Fibre \& Textile Research 42(1): 111-117. 